\title{
COMPARATIVE ANALYSIS OF PRODUCTION - LOGISTICS SYSTEMS THAT BASED ON PUSH AND PULL STRATEGIES
}

\author{
O. M. Zagursky, T. I. Slipukha
}

National University of Life and Environmental Sciences of Ukraine, Ukraine.

Corresponding authors: zagurskiy_oleg@ukr.net.

Article history: Received: March 2019. Received in the revised form: April 2019. Accepted: August 2019. Bible 15, fig.4, tab 5.

Abstract. A comparison is made of production and logistics strategies based on Push and Pull strategies and the advantages and disadvantages of their application to the enterprise are analyzed. This makes it possible to make a choice between flow management systems according to the market conditions and the characteristics of internal processes in the enterprise.

Was presented a mathematical model of choosing the construction`s principle of production-logistics system of the enterprise and practical recommendations for its implementation. A system of indicators characterizing the efficiency of the production and logistics system of the enterprise has been formed. The following indicators have been identified as key criteria influencing decisionmaking when choosing a production and logistics system: reliability of the supplier; availability of warehouse space; fluctuations in demand; productivity; quality of production.

The evaluation of the indicators of JSC "Milk Alliance" showed that at this point in time the production and logistics system of the enterprise most fully meets the requirements of the pushing concept of flow management. At the same time, the analysis provided an opportunity to identify the directions that the company needs to work on in order to further transition to the principles of the pulling concept, namely the need to improve interactions with existing suppliers and search for new suppliers. It is determined that the selected problems at the enterprise are important factors of construction of production and logistics systems on the principles of extraction. Therefore, they can be used as criteria that influence the decision on the choice of production and logistics concept.

Key words: production - logistics system, flexibility, inventories, concepts of flow management, efficiency criteria, system of indicators.

\section{Introduction}

Given the new economic conditions, an effective production and logistics system must meet such requirements as rapid response to changing demand, reducing the level of all types of inventory, fulfilling orders with high quality of service and more. In this regard, in the design of modern production - logistics systems, work is underway to replace the sale policy of manufactured goods with the production policy of goods sold; minimizing the time of production through the technological process, reducing the batch of resources and batch processing, reducing all types of downtime and inefficient intra-industrial transportation.

\section{Formulation of problem}

Accordingly, more and more implementation is underway with "dynamic" production and logistics systems, which allow to satisfy the needs of the clients most fully and meet the requirements of the economy of post-industrial society. In particular, they are built on the principle of pulling consumers to points of sale, which provides flexibility and high level of service, thus creating the conditions for a quick response to changing customer requests. At the same time, the factors analysis that influence the overall choice of production-logistics system strategy shows that the "cost-effective" option of the strategy, aimed at reducing all types of costs, is fully justified in conditions when demand is demanded, the requirements for diversity are limited and the volume of production is high. In this sense, scientific approaches, practical methods and models for choosing a method of managing production and logistics systems based on different concepts of material flow management and the indicators that form them are of particular interest for research.

\section{Analysis of recent research results}

In today's economy, one of the basic competitive advantages of any organization is the ability to quickly and efficiently meet customer requests according to their requirements. The most important tool in the process of achieving this goal is the focus of the organization as a whole, because it is the formation of an effective system of promotion of goods along the supply chain, allows you to deliver the necessary goods to the consumer at the right 
place, time, quantity and quality and at the lowest cost. Today, especially in foreign practice, there are many approaches to determining the performance indicators of production and logistics systems. Thus, A. Gunasekaran, S. Patel, E. Tirtiroglu propose a system of performance indicators, classified by processes [1]. Houseman considers the distribution of metrics by types of flows [2]. Chan and $\mathrm{Ki}$ subdivide performance appraisal indicators into groups: quantitative (cost, lead time, production capacity and resources) and qualitative (customer satisfaction, degree of flexibility, integration of information and material flows, risk management and supplier performance) [3].

However, taking into account or using certain scientific approaches does not guarantee the undoubted efficiency of the production and logistics system of the enterprise. A combination of adverse external factors (fluctuations in prices, arbitrary increases in supply parties, deviations from production schedules, and the like, etc.) can lead to disruptions or failures in the supply chain, and consequently reduce the reliability of supply and increase the costs of the enterprise. Therefore, one of the most difficult problems that management faces in modernizing the production and logistics system of the enterprise is the choice of a way to manage the goods flows, which is determined based on the overall goals of the company, market situation, features of the processes of the enterprise and other factors. Thus, the management of the enterprise is faced with a multicriteria problem, which solution can be used in different ways. The following methods of solving such problems are distinguished in science: utility theory method [4], criterion importance theory $[5 ; 6]$, the weighted sum method $[7 ; 8]$ method of hierarchy analysis $[9 ; 10$.$] .$ However, despite the abundance of scientific research in this area, it should be emphasized that a number of conceptual and methodological tasks are underdeveloped and require further study, in particular regarding the choice of how to manage the flow of goods in the enterprise.

\section{Purpose of research}

Development of methodological provisions for the design of production and logistics systems based on the pulling concept of flow management, as well as the development of models to choose the principle of construction of production and logistics system and practical recommendations for its implementation. To achieve this goal the following tasks were solved:

- refinement of methodological approaches to the design of production and logistics systems based on the pulling concept of flow management;

- development of a mathematical model of decisionmaking on the choice of the principle of construction of production and logistics system of the enterprise;

- formation of a system of indicators characterizing the efficiency of the production and logistics system of the enterprise.

\section{Results of research}

In modern science and practice, the issues of designing logistics systems of enterprises are given much attention, which is primarily due to the subject of their research - flows. Their diversity - material, labor, service, information, energy, financial - requires a clear organization and synchronization with each other not only within the enterprise, but throughout the supply chain. The lack of common principles for flow management makes it impossible to use the synergistic effect of their combination and leads to loss of the entire production and logistics system. The main information taken into account in the development of production and logistics systems is information on the market, production, material and information flows. Therefore, the research is based on modern scientific approaches in the field of logistics, marketing and management. Thus, in the logistics and marketing activities distinguish two basic principles of material flow management: ejection and extraction. Accordingly, production and logistics strategies based on these principles were called Push and Pull strategies.

Manufacturing and logistics system, pushing type (Figure 1), means an adaptive system that performs certain production and logistics functions, which is based on the principle of transferring the resource from the previous link of the logistics chain to the next according to a centralized delivery schedule. In it, the main focus is on material flow planning based on demand forecasts, and production and trade "push" their goods to points of sale according to the delivery schedule and do not depend on the needs of customers.

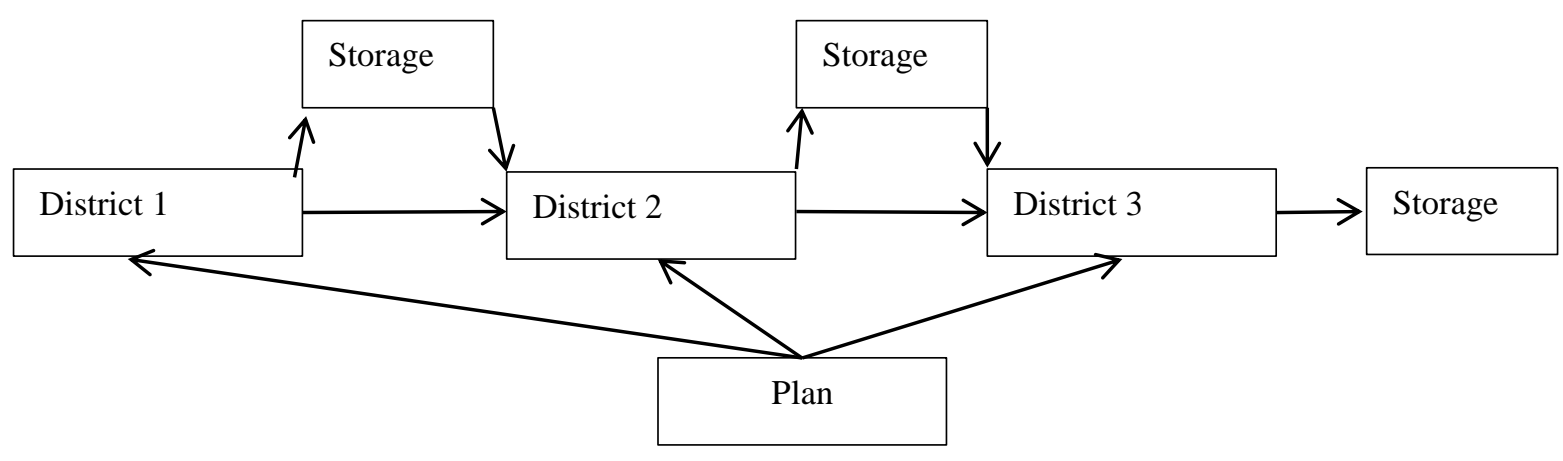

Fig. 1. The scheme of Push Strategy. 
Production - logistics system based on the pulling concept (Fig. 2) can be described as an adaptive feedback system that performs certain production and logistics operations based on the principle of transferring the resource from the previous link of the production and logistics chain the following at the request of the end consumer, the customer. In it the buyer is "attracted" to the point of sale and the signal for the beginning of the production process is also given by the consumer.

\section{Order}

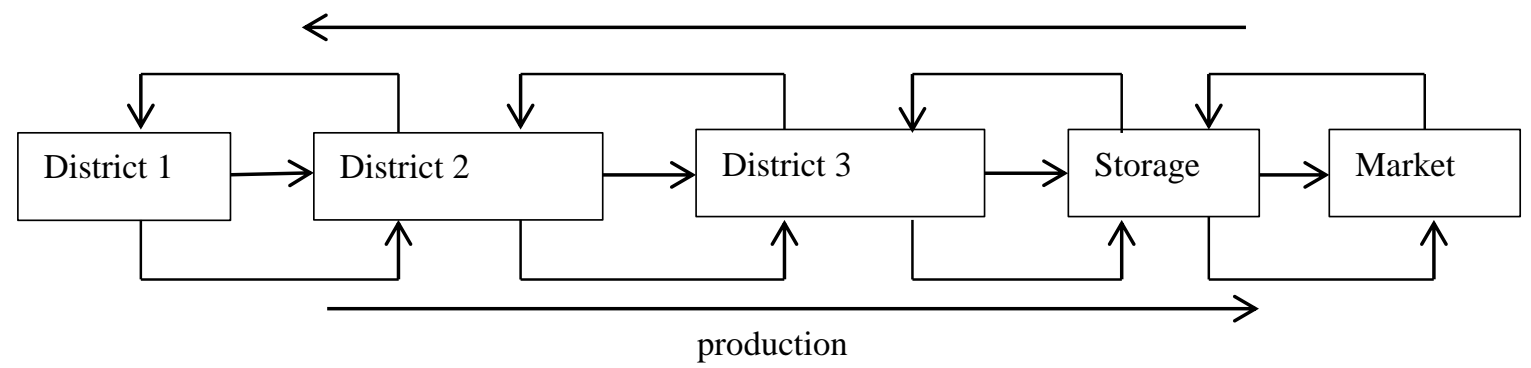

Fig. 2. The scheme of Pull Strategy.

The purpose of both concepts is to meet the needs of the next link at the expense of the previous one's resources. The main and defining differences of production and logistics systems based on pushing and pulling concepts are:

- flow control method;

- the degree of centralization of supply planning for inter-link transmissions;

- approaches to establishing the rhythm that determines the movement of material flow.

Each method of organization of production and logistics system has strengths and weaknesses that influence the strategy of enterprise development. Thanks to the basic characteristics of the pulling concept (flexibility, high quality of service, reduction of inventory standards), the flow management system makes it possible to respond quickly to changes in customer requests. As a result of its construction, the company shortens the production cycle, increases the turnover of inventories and, in fact, carries out work to order. At the same time, the principle of extraction requires timeliness and quality of deliveries, as they ensure the operation of the entire production process in the absence of stocks or their minimum size. Similarly, the system does not provide input quality control, so the reliability of supplying quality materials is one of the main conditions.

Considering the strengths of the push system, it is possible to note its stability and the possibility of organizing the input control, which allows to ensure the satisfaction of stable high demand. However, it also has drawbacks, namely the lack of clarity in demand tracking and the mandatory availability of insurance reserves and reserves. Therefore, for this system, demand fluctuations are extremely negative. Reserves that allow for fluctuations require significant financial costs, additional storage space and manpower from the system.

Accordingly, the management of the enterprise in the design of production and logistics system is tasked with choosing between pushing strategies focused on mass production planned production and pulling, which focus on the production of small batches at the request of the consumer. Assessment of the strengths and weaknesses of the concept allows the company to choose between flow management systems according to their market conditions and the characteristics of internal processes in the enterprise. At the same time it is necessary to adhere to generally accepted principles of strategy development, such as systematic, adaptability, global optimization, logistical coordination and integration.

The first stage in the design of the production and logistics system is goal setting. The company can set the following types of goals: 1) Achieving certain values of the market share indicator.2) Increasing the efficiency of activities that are necessary when the needs of consumers are not met or are not met at the expense of resources high costs, ie with inefficient use of capital, staff and production and technical potential of the company.

This step is crucial because it allows us to formulate a vision for the future of the company [11].

After defining the goal, the management of the company must make a choice between the type of production and logistics system, that is, identify the appropriateness of using an enterprise system based on pulling or pushing concepts. This can be done through a detailed examination of the company specificity, market conditions, geographical location and other factors, using methods of mathematical and economic modeling. However, when designing a production and logistics system, it is important to understand that the object is the processes that occur in the enterprise in real time and meet the current economic conditions. To choose an alternative strategy of production-logistics system of the enterprise we use the method of hierarchy analysis (MHA). The purpose of the method is to justify the best choice of the proposed alternatives, the characteristics of which are vectors with heterogeneous, including with indeterminate, separate components [12].

The essence of the method of analysis of hierarchies lies in the step-by-step solution of such interconnected individual problems as:

- construction of indicators hierarchical structure;

- evaluation of the hierarchical arrangement of individual indicators for each hierarchy's level;

- comparison of available alternatives and choosing the best one. 
This method seems simple, straightforward and easy to calculate. Accordingly, it is widely used in practical activities to perform decision-making tasks in different productions: to choose one best or several best options, to sort (rank) all the options by preference, etc.

The following are the advantages of using the MHA over other methods of selecting alternative projects and prioritizing them.

- uses a hierarchical structure and enables decisionmakers to determine the level of strategic goals and specific indicators to better assess strategic alignment.

- goes beyond financial analysis as a result of integrating quantitative and qualitative parameters.

- enables decision makers to measure the relative importance of projects, including their benefits, costs, risks and opportunities, leading to more efficient use of funds.

- can be applied to any organization with any level of maturity, since the data is normalized using numerical estimates or expert judgment when the required indicators are unavailable.

- is subjected to sensitivity analysis, which provides a greater number of analytical capabilities when considering a particular scenario [13].

For choosing the constructions principle of production-logistics system, we will evaluate the state of the enterprise and the possibility of implementing the system in the existing conditions. Based on the level of indicators, we can conclude on which system at a given moment conditions are most fully meet its requirements. At the same time, we will evaluate the directions that the enterprise needs to improve in order to further transition from one system to another.

Since the study of company performance is carried out at the current time, the solution of the problem will occur in the conditions of certainty. Thus, we construct a model of linear decision-making programming under certainty. There are many variants of system $\mathrm{V}$

where $\mathrm{V}_{1}$ - is pull system,

$$
\mathrm{V}=\left(\mathrm{V}_{1} ; \mathrm{V}_{2}\right)
$$

$\mathrm{V}_{2}-$ is push system.

Each variant of $\mathrm{Vi}$ is characterized by the values of the $\mathrm{Xi}$ criteria. That is, for each variant there is a vector criterion $\mathrm{X}$

$$
\left.\mathrm{X}=\mathrm{X}_{1}, \ldots \mathrm{X}_{\mathrm{n}}\right)
$$

where $\mathrm{n}$ - is number of criteria,

$\mathrm{Xi}$ takes a value from the set $\mathrm{Ni}$ (scale)

The objective function in this case will be represented by an additive function:

$$
\mathrm{h}(\mathrm{x})=\mathrm{a}_{1} \mathrm{n}_{1}(\mathrm{x})+\mathrm{a}_{2} \mathrm{n}_{2}(\mathrm{x})+\ldots+\mathrm{a}_{\mathrm{m}} \mathrm{n}_{\mathrm{m}}(\mathrm{x}) \rightarrow \max
$$

where $a_{i}-$ is degree of criterion's significance(its relative weight),

$\mathrm{n}_{\mathrm{m}}$ (x) - is the level of its importance in the enterprise.

The whole set of $\mathrm{n}$ criteria under consideration should cover key procurement, production, and consumption processes that are important for both the towing and the pushing systems.
As criteria that influence the decision-making on the choice of production and logistics concept we have selected the following indicators:

- Supplier reliability is a particularly important criterion for the pull strategy in which suppliers and their relationships with suppliers are key;

- availability of warehouse space - the criterion is more inherent in the pushing strategy, since fuzzy demand tracking implies the availability of insurance stocks;

- fluctuations in demand - a criterion characteristic of both concepts, but due to the low flexibility of greater impact it has a pushing strategy where fluctuations in demand can lead to more negative consequences;

- labor productivity is a factor that has a great impact on both alternatives, because for the extraction principle it provides a short production cycle and for the ejection - the efficiency of the whole system, which is directly dependent on the volume of production and income;

- the quality of the products produced is also a factor that matters for both systems. The quality level must be assessed both at the entrance to the production logistics system and at the exit. Both factors are extremely important for the hauling system. Lack of input control causes increased responsibility of suppliers, and lack of inventory makes the quality of manufactured products one of the priority tasks of production, because each unit of defective goods generates the need to create a buffer.

In view of the peculiarities of the first two criteria and their impact on the production-logistics systems of different types, we will divide them into additional indicators 1 (coefficient of supply`s volume, coefficient of supplies quality, coefficient of materials supplied quality; factor of supplier`s distance), 2 (coefficient of supply) the maintenance of work in progress, the coefficient of area security of finished products retention, the factor of area security of raw materials retention). Thus, the system of indicators that influence the decision on the choice of production and logistics concept has the following form.

The integrated coefficient of each indicator is calculated as the weighted average of the partial coefficients.

$$
N_{i}=\frac{n_{1}+n_{2}+\ldots+n_{i}}{i}
$$

The Ni ratio indicates what level each of the metrics in the enterprise is. Moreover, each indicator of ni is compared to its significance level for $\mathrm{Ni}$ analysis. In order to evaluate this level, you must arrange all the indicators by their degree of importance so that the rule $n 1>n 2>\ldots$ ni is satisfied. Ranking is by Fishburn rule [14]:

$$
\mathrm{n}_{\mathrm{i}}=\frac{2(\mathrm{n}-\mathrm{i}+1)}{(\mathrm{n}-1) \mathrm{n}}
$$

And if we assume that the development's level of the production-logistics system of the enterprise is equal to 1 , then the matrix "A" constructed using the method of pairwise comparisons will have the form. 
Table 1. System of indicators that influence decision making when choosing a production - logistics concept.

\begin{tabular}{|c|c|c|c|}
\hline Index & Indicator & $\begin{array}{c}\text { Partial } \\
\text { coefficient }\end{array}$ & $\begin{array}{l}\text { Integrated } \\
\text { coefficient }\end{array}$ \\
\hline \multirow[t]{4}{*}{ Provider reliability } & Delivery ratio & $\mathrm{n}_{1}$ & \multirow[t]{4}{*}{$\mathrm{N}_{1}$} \\
\hline & The timeliness of deliveries & $\mathrm{n}_{2}$ & \\
\hline & Quality factor of the supplied materials & $\mathrm{n}_{3}$ & \\
\hline & Vendor Remoteness Ratio & $\mathrm{n}_{4}$ & \\
\hline \multirow[t]{3}{*}{$\begin{array}{l}\text { Existence of warehouse } \\
\text { areas }\end{array}$} & $\begin{array}{l}\text { The coefficient of security of the area of } \\
\text { maintenance of work in progress }\end{array}$ & $\mathrm{n}_{5}$ & \multirow[t]{3}{*}{$\mathrm{N}_{2}$} \\
\hline & $\begin{array}{l}\text { The coefficient of security of the area of } \\
\text { retention of finished products }\end{array}$ & $\mathrm{n}_{6}$ & \\
\hline & $\begin{array}{l}\text { The coefficient of availability warehouse of } \\
\text { raw materials retention }\end{array}$ & $\mathrm{n}_{7}$ & \\
\hline Fluctuations in demand & $\begin{array}{l}\text { Coefficient of actual sales deviation from } \\
\text { planned }\end{array}$ & $\mathrm{n}_{8}$ & $\mathrm{~N}_{3}$ \\
\hline Productivity & The level of productivity & $\mathrm{n}_{9}$ & $\mathrm{~N}_{4}$ \\
\hline $\begin{array}{l}\text { The quality of the } \\
\text { products }\end{array}$ & Quality factor of the produced products & $\mathrm{n}_{10}$ & $\mathrm{~N}_{5}$ \\
\hline
\end{tabular}

Source: prepared by the author

$$
A=\left(\begin{array}{lllll}
1 & \frac{N_{1}}{N_{2}} & \frac{N_{1}}{N_{3}} & \frac{N_{1}}{N_{4}} & \frac{N_{1}}{N_{5}} \\
\frac{N_{2}}{N_{1}} & 1 & \frac{N_{2}}{N_{3}} & \frac{N_{2}}{N_{4}} & \frac{N_{2}}{N_{5}} \\
\frac{N_{3}}{N_{1}} & \frac{N_{3}}{N_{2}} & 1 & \frac{N_{3}}{N_{4}} & \frac{N_{3}}{N_{5}} \\
\frac{N_{4}}{N_{1}} & \frac{N_{4}}{N_{2}} & \frac{N_{4}}{N_{3}} & 1 & \frac{N_{4}}{N_{5}} \\
\frac{N_{5}}{N_{1}} & \frac{N_{5}}{N_{2}} & \frac{N_{5}}{N_{3}} & \frac{N_{5}}{N_{4}} & 1
\end{array}\right)
$$

The matrix "A" allows you to evaluate which indicators in the enterprise are more important. For this purpose, a normalized matrix "A" is calculated by dividing the elements of each matrix "A" column by the sum of the elements of these columns.

$$
A=\left(\begin{array}{lllll}
a_{11} & a_{12} & a_{13} & a_{14} & a_{15} \\
a_{21} & a_{22} & a_{21} & a_{24} & a_{25} \\
a_{31} & a_{32} & a_{33} & a_{34} & a_{35} \\
a_{41} & a_{42} & a_{43} & a_{44} & a_{45} \\
a_{51} & a_{52} & a_{53} & a_{54} & a_{55}
\end{array}\right)
$$

Then to determine the proportion of each indicator in the level of enterprise`s processes we find the average value of the line items:

$$
A=\left(\begin{array}{l}
a_{1} \\
a_{2} \\
a_{3} \\
a_{4} \\
a_{5}
\end{array}\right)
$$

The assessment of the processes importance for each systems is made taking into account the experience of specific enterprises. To do this, we add a pairwise

\begin{tabular}{|c|c|c|c|c|c|c|}
\hline Index & 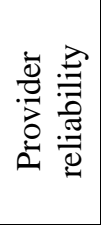 & 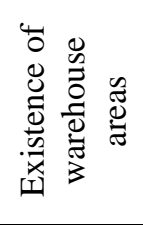 & 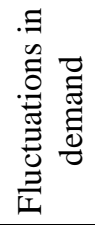 & 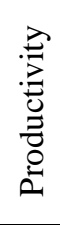 & 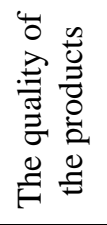 & $\underset{0}{\tilde{0}}$ \\
\hline Provider reliability & 1 & 1 & 1 & 1 & 1 & 5 \\
\hline Existence of warehouse areas & 0 & 1 & 0 & 0 & 0 & 1 \\
\hline Fluctuations in demand & 0 & 1 & 1 & 0 & 0 & 2 \\
\hline Productivity & 0 & 1 & 1 & 1 & 0 & 3 \\
\hline Provider reliability & 0 & 1 & 1 & 1 & 1 & 4 \\
\hline
\end{tabular}
comparison matrix (Tables 2,3.)

Table 2. The matrix of pairwise comparison of indicator`s importance for the pull-system. 
Table 3. The matrix of pairwise comparison of indicator`s importance for the push system.

\begin{tabular}{|c|c|c|c|c|c|c|}
\hline Index & 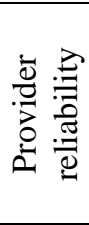 & 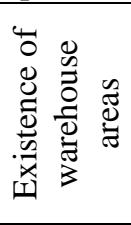 & 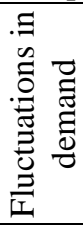 & $\begin{array}{l}\stackrel{2}{D} \\
.0 \\
0 \\
0 \\
0 \\
0\end{array}$ & 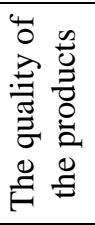 & $\stackrel{\overparen{\pi}}{0}$ \\
\hline Provider reliability & 1 & 0 & 0 & 0 & 1 & 2 \\
\hline Existence of warehouse areas & 1 & 1 & 0 & 1 & 0 & 3 \\
\hline Fluctuations in demand & 1 & 1 & 1 & 1 & 1 & 5 \\
\hline Productivity & 1 & 0 & 0 & 1 & 1 & 3 \\
\hline The quality of the products & 0 & 1 & 0 & 0 & 1 & 2 \\
\hline
\end{tabular}

Source: prepared by the author

Table 4. Criteria for evaluating the importance of indicators for pull and push systems.

\begin{tabular}{|l|c|c|c|c|}
\hline \multirow{2}{*}{ Index } & \multicolumn{3}{c|}{ The degree of importance } \\
\cline { 2 - 5 } & pull & coefficient & push & coefficient \\
\hline Provider reliability & 5 & 0,33 & 2 & 0,07 \\
\hline Availability warehouse areas & 1 & 0,07 & 3 & 0,27 \\
\hline Fluctuations in demand & 2 & 0,13 & 5 & 0,33 \\
\hline Productivity & 3 & 0,2 & 3 & 0,2 \\
\hline The quality of the products & 4 & 0,27 & 2 & 0,13 \\
\hline
\end{tabular}

Thus, the hierarchy of decision-making is as follows:

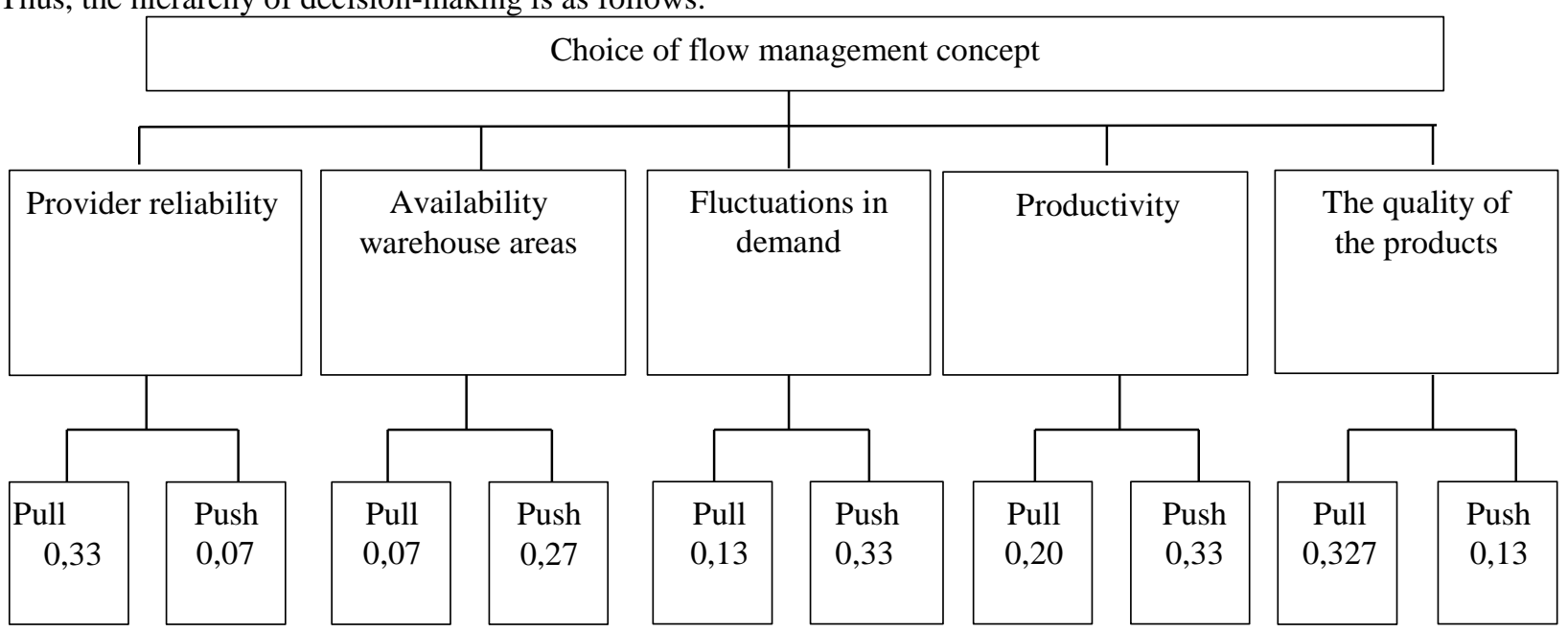

Fig. 3. The hierarchy of decision making for the choice of logistics concept.

In fact, tables 2 and 3 define the importance criteria for a given production-logistics system. It should be noted that in scientific research there is no precise formal definition of the criteria'i importance, so as a rule this task is solved by an informal method, involving experts who come from their own understanding about the importance of individual indicators. As a result, we get criteria for evaluating the importance of indicators for both systems.

The purpose of both concepts is to meet the needs of the The estimation of the two systems is based on the calculation of the combined weighting factor for each of them.

Push: $0,33 \mathrm{~N}_{1}+0,07 \mathrm{~N}_{2}+0,13 \mathrm{~N}_{3}+0,20 \mathrm{~N}_{4}+0,27$ $\mathrm{N}_{5}=\mathrm{x}_{1}$. $\mathrm{N}_{5}=\mathrm{x}_{2}$.

Pull: $0,07 \mathrm{~N}_{1}+0,27 \mathrm{~N}_{2}+0,33 \mathrm{~N}_{3}+0,33 \mathrm{~N}_{4}+0,13$

Accordingly, a system that has a combined weight ratio is greater and is optimal for a given enterprise when available.

Let's calculate the value of indicators for JSC "Milk Alliance" (Table 5).
The values of the indicators that influence the decision making when choosing a production-logistics concept for JSC "Milk Alliance".

Pull: $0,33 * 0,56+0,07 * 0,64+0,13 * 0,8+0,2 *$ $1,22+0,27 * 0,97=0,84$.

Push: $0,07 * 0,56+0,27 * 0,64+0,33 * 0,8+0,33 *$ $1,22+0,13 * 0,97=0,99$.

The results show that today it is more profitable to use a pushing production and logistics system at the enterprise. And in view of the weight and significance of the criteria, in order to switch to the Milk Alliance JV flow management system, it is first necessary to pay attention to working with suppliers, improving relationships with them or finding new suppliers.

If it is impossible to implement a pulling strategy (as in the object of research), the company needs to conduct an analysis of factors that impede the change of production and logistics system. When identifying a problem and finding a solution, an important aspect is to eliminate the underlying causes of the discrepancy. 
Table 5. The values of the indicators that influence the decision making when choosing a production and logistics concept for JSC "Milk Alliance".

\begin{tabular}{|c|c|c|c|}
\hline Index & Indicator & Partial coefficient & $\begin{array}{l}\text { Integrated } \\
\text { coefficient }\end{array}$ \\
\hline \multirow[t]{4}{*}{$\begin{array}{l}\text { Provider } \\
\text { reliability }\end{array}$} & Delivery ratio & $n_{1}=\frac{4754520}{5150380}=0.92$ & \multirow[t]{4}{*}{$\mathrm{N}_{1=0,56}$} \\
\hline & The timeliness of deliveries & $n_{2}=\frac{10 \text { nocmaч } / \text { мic }}{13 \text { nocmaч } / \text { мic }}=0.77$ & \\
\hline & $\begin{array}{l}\text { Quality factor of the supplied } \\
\text { materials }\end{array}$ & $n_{3}=\frac{148 \mathrm{~m} / \text { Mic }}{151 \mathrm{~m} / \text { Mic }}=0.98$ & \\
\hline & Vendor Remoteness Ratio & $n_{4}=90 \% \geq 100 \mathrm{kM}=0.1$ & \\
\hline \multirow[t]{3}{*}{$\begin{array}{l}\text { Availability } \\
\text { warehouse } \\
\text { areas }\end{array}$} & $\begin{array}{l}\text { Коефіцієнт забезпеченості площі } \\
\text { утримання НЗВ }\end{array}$ & $n_{5}=\frac{120220}{124610}=0.96$ & \multirow[t]{3}{*}{$\mathrm{N}_{2}=0,64$} \\
\hline & $\begin{array}{l}\text { Коефіцієнт забезпеченості площі } \\
\text { утримання ГП }\end{array}$ & $n_{6}=\frac{90000}{94500}=0.95$ & \\
\hline & $\begin{array}{l}\text { The coefficient of availability } \\
\text { warehouse area of raw materials } \\
\text { retention }\end{array}$ & $n_{7}=\frac{148000}{145500}=1,02$ & \\
\hline $\begin{array}{l}\text { Fluctuations in } \\
\text { demand }\end{array}$ & $\begin{array}{l}\text { Coefficient of actual sales deviation } \\
\text { from planned }\end{array}$ & $n_{8}=\frac{5360800 \text { грн / мiс }}{6742000 г \text { грн / мiс }}=0.8$ & $\mathrm{~N}_{3}=0,8$ \\
\hline Productivity & The level of productivity & $n_{9}=\frac{12100}{9900}=1,22$ & $\mathrm{~N}_{4}=1,22$ \\
\hline $\begin{array}{l}\text { The quality of } \\
\text { the products }\end{array}$ & $\begin{array}{l}\text { Quality factor of the produced } \\
\text { products }\end{array}$ & $n_{10}=\frac{1450 \mathrm{~m} / \text { Mic }}{1490 \mathrm{~m} / \text { Mic }}=0.97$ & $\mathrm{~N}_{5}=0,97$ \\
\hline
\end{tabular}

\section{Source: prepared by the author}

In this case, all obstacles to the construction of the pulling concept can be divided into bulk and insurmountable. The insurmountable causes, as a rule, lie in the external environment of the company, which cannot be influenced, first of all, by the nature of consumption or the specificity of production technology, its dependence on chemical or biological processes. In this case, the company is forced to find other tools to achieve this goal. Overcoming obstacles, as a rule, are the characteristics of the internal environment of the company. For example, features of interaction between workshops, departments, suppliers, customers, etc.

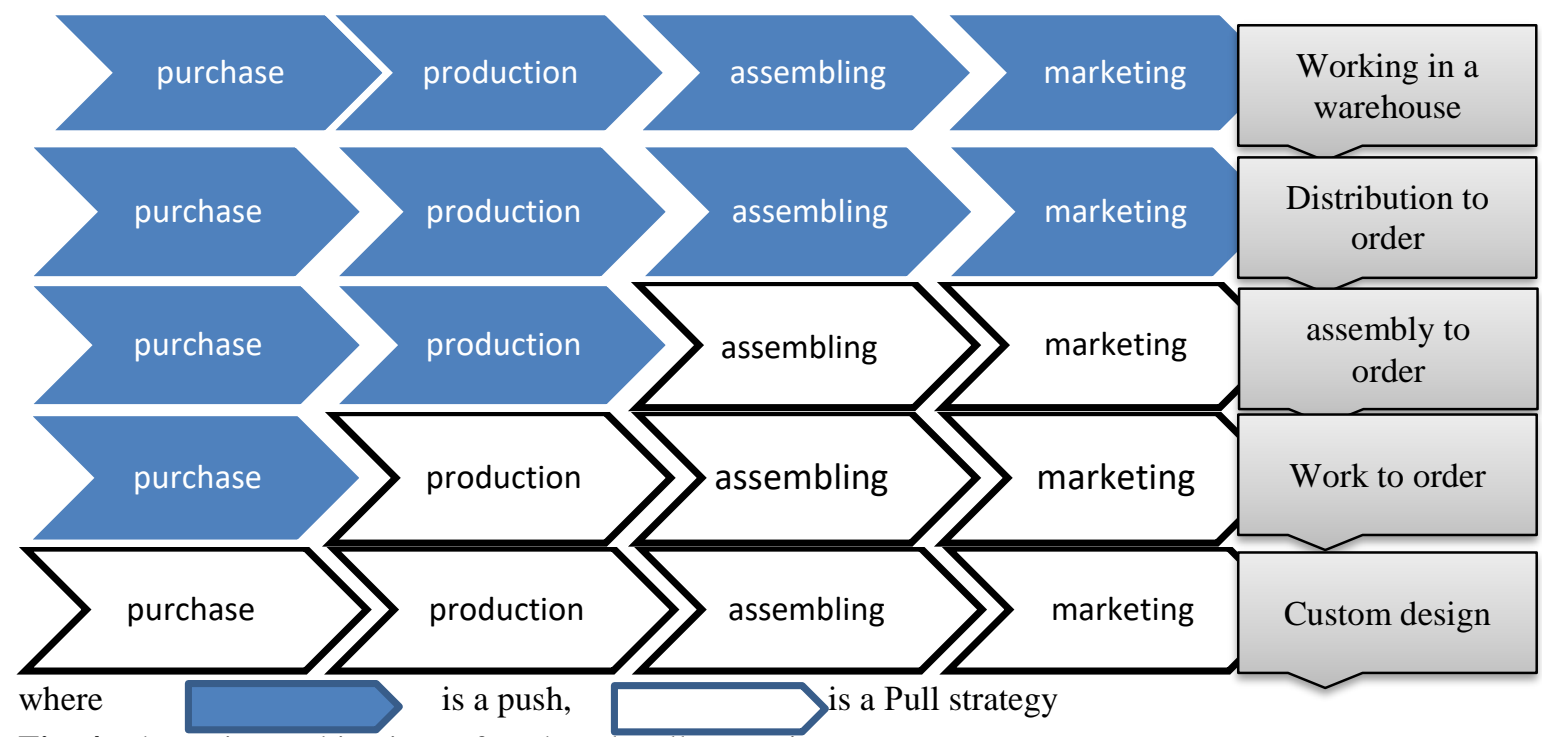

Fig. 4. The main combinations of Push and Roll strategies.

Source: prepared by the author 
When working with them should develop a plan for solving the problem and the stages of its implementation. After eliminating the root causes, you can return to assessing the possibility of building a traction system.

However, in practice, basic types of pushing or pulling production and logistics systems in a "clean" form are rarely used. Typically, enterprises combine ways to eliminate bottlenecks based on their own technological process. And if you can conditionally divide the supply chain into the following stages: procurement, production, installation and marketing, there are five major combinations of Push and Pull strategies: warehousing, custom distribution, build-to-order, work-to-order and custom design.

Most desirable for businesses in most sectors of the economy is the closest possible approach to a full Pull strategy (custom design). After all, the pulling concept of logistics is universal and can be applied in the construction of production and logistics system in any field of activity. Dennis Hobbs [15] clearly identifies the six stages of building a production and logistics system based on a pulling concept.

1. Initialization and launch of the project. This stage contains the formulation of a strategic vision for the future company, determining the composition of teams and training participants, drawing up a plan of action, defining the powers of teams, their tasks, organizing the collection of information necessary for the design of supply chains on a pulling basis.

2. Documenting products, processes and materials.

3. The stage of final review, which is to complete the information-gathering activities, ie to reach consensus and approve management decisions on products, volumes and working minutes per day on the drawing line.

4. Production capacity planning. The purpose of this phase is to create an extraction strategy model based on the estimated volume of resources.

5. Commissioning of the line. At this stage, the clock and switching time of operators are synchronized; the correctness of the distribution of tasks across workplaces and ergonomic planning of the workplace are checked; a plan is made to reduce work in progress; a mechanism for continuous improvement of the process is introduced.

6. Assimilation, that is, checking the operation of the line and assessing its compliance with the criteria of the drawing concept. At this final stage, deviations are identified and correction strategies are developed.

The measures carried out generally contribute to improving the efficiency of the production and logistics system of the enterprise and its profitability, respectively. In the future, to create value flow for internal and external consumers, it is necessary to transform them into a sequence of processes. Turning supply chains into streams also means the continuity of the flow of resources that are processed in business processes in a rhythm that is set by consumers on a pull-out basis, thereby automatically building a supply system "on time."

\section{Conclusions}

1. When constructing and designing a production and logistics system based on the pulling principle of flow management, it is necessary to adhere to the basic principles: systematicity, adaptability, global optimization, logistical coordination and integration, development of a corresponding complex of subsystems. It is important to constantly improve processes, which, in the context of regular changes, can improve and maintain the efficiency of the system as a whole.

2. Assessing the feasibility of implementing the concept at the enterprise is an important step in building a production and logistics system, as it selects the concept of flow management. In order to make a decision, the study used the method of analysis of the AHI hierarchy, which made it possible to substantiate the choice of the best alternative strategy for JSC "Milk Alliance". The analysis showed that the performance of the company at this point in time most fully meet the requirements of a pushing production and logistics flow management system, and at the same time gave the opportunity to identify the directions that need to work to further the transition to the principles of pulling concept. Selected problems at the enterprise are important factors in the construction of production and logistics systems based on the principles of extraction. Therefore, they can be used as criteria that influence the decision on the choice of production and logistics concept.

\section{References}

1.Gunasekaran A., Patel, C., Tirtiroglu E. (2001). Performance measures and metrics in a supply chain environment. International Journal of Operations \& Production Management. Vol. 21, №.1/2, 71-87.

2.Hausman W. (2018). Financial Flows \& Supply Chain Efficiency/Visa Commercial Solutions URL: http://www.visaasia.com/ap/sea/commercial/corporates/in cludes/ uploads/Supply_Chain_Management_Visa.pdf.

3. Chan F. T., Qi H. J. (2003). An innovative performance measurement method for supply chain management. Supply Chain Management: An International Journal. Vol. 3. 209-223.

4.Leenders M. R., Johnson P. F., Flynn A. E., Fearon H. E. (2006). Purchasing and Supply Management, 13 th edition. McGraw-Hill. 768.

5.Figueira J., Greco S., Ehrgott M. (2005). Multiple criteria decision analysis: state of the art surveys. NewYork: Springer. 1035.

6.Podinovski V. V. (1994). Criteria importance theory. Mathematical Social Sciences. Vol. 27. 237-252.

7.Belton V., Stewart T. J. (2002). Multiple criteria decision analysis: an integrated approach. Boston: Cluwer. 372.

8.Branke J., Deb K., Miettinen K., Sownski R. (2008). Multiobjective optimization: interactive and evolutionary approaches. NY: Springer. 470.

9. Odnorog M. A. (2015). Investment support for completed projects at agricultural enterprises. Actual Problems of Economics. № 7. 180-185.

10. Saaty T. L. (1982). Decision Making for Leaders: The Analytic Hierarchy Process for Decisions in a Complex World. Belmont, Calif.: Lifetime Learning Publications, 291. 
11. Drake, P. R. (1998). Using the Analytic Hierarchy Process in Engineering Education. International Journal of Engineering Education. Vol. 14 (3). 191-196.

12. Saaty T. L. (1996). The Hierarchon: A Dictionary of Hierarchies. Pittsburgh, Pennsylvania : RWS Publications. 510.

13. Kendrick J. D., Saaty D. (2007). Use Analytic Hierarchy. Process For Project Selection. Six sigma forum magazine. 22-29. URL: http://engexecforum.com/ external\%20files/Use \%20Analytic\%20Heirarch\%20for\% 20Project\%20Selection.pdf.

14. Fishburn P. (1968). Utility Theory. Management Science. Vol. 14, No. 5. 335-378.

15. Hobbs D. P. (2003). Lean Manufacturing Implementation: A Complete Execution Manual for Any Size Manufacturer J. Ross Publishing. 264.

\section{Список літератури}

1.Gunasekaran A., Patel, C., Tirtiroglu E. Performance measures and metrics in a supply chain environment. International Journal of Operations \& Production Management. 2001. Vol. 21, №.1/2, P. 71-87.

2.Hausman W. Financial Flows \& Supply Chain Efficiency/Visa Commercial Solutions URL: http://www.visaasia.com/ap/sea/commercial/corporates/in cludes/ uploads/Supply_Chain_Management_Visa.pdf.

3.Chan F. T., Qi H. J. An innovative performance measurement method for supply chain management. Supply Chain Management: An International Journal. 2003. Vol. 3. P. 209-223.

4.Leenders M. R., Johnson P. F., Flynn A. E., Fearon H. E. Purchasing and Supply Management, 13 th edition, 2006. McGraw-Hill. 768 p.

5.Figueira J., Greco S., Ehrgott M. Multiple criteria decision analysis: state of the art surveys. NewYork: Springer, 2005. $1035 \mathrm{p}$.

6.Podinovski $V$. V. Criteria importance theory. Mathematical Social Sciences. 1994. Vol. 27. P. 237-252.

7.Belton V., Stewart T. J. Multiple criteria decision analysis: an integrated approach. Boston: Cluwer, 2002. $372 \mathrm{p}$.

8.Branke J., Deb K., Miettinen K., Sownski R. Multiobjective optimization: interactive and evolutionary approaches. NY: Springer, 2008. 470 p.

9. Odnorog M. A. Investment support for completed projects at agricultural enterprises. Actual Problems of Economics, 2015. № 7. P. 180-185.

10. Saaty T. L. Decision Making for Leaders: The Analytic Hierarchy Process for Decisions in a Complex World. Belmont, Calif.: Lifetime Learning Publications, 1982, $291 \mathrm{p}$

11. Drake, $P . R$. Using the Analytic Hierarchy Process in Engineering Education. International Journal of Engineering Education. 1998. Vol. 14 (3). 191-196.

12. Saaty T. L. The Hierarchon: A Dictionary of Hierarchies. Pittsburgh, Pennsylvania : RWS Publications, 1996. $510 \mathrm{p}$.

13. Kendrick J. D., Saaty D. Use Analytic Hierarchy. Process For Project Selection. Six sigma forum magazine. 2007. P. 22-29. URL: http://engexecforum.com/
external\%20files/Use \%20Analytic\%20Heirarch\%20for\% 20Project\%20Selection.pdf.

14. Fishburn $P$. Utility Theory. Management Science. 1968. Vol. 14, No. 5. P. 335-378.

15. Hobbs $\quad$ D. $\quad P$. Lean Manufacturing Implementation: A Complete Execution Manual for Any Size Manufacturer J. Ross Publishing, 2003. 264 p.

\section{ПРОЕКТУВАННЯ ВИРОБНИЧО-ЛОГІСТИЧНИХ СИСТЕМ НА ОСНОВІ ТЯГНУЧОЇ КОНЦЕПЦІЇ УПРАВЛІННЯ ПОТОКАМИ \\ О. М. Загурський, Т. I. Сліпуха}

Анотація. Досліджено особливості проектування виробничо-логістичних систем на основі тягнучої концепції управління потоками. Ї̈̈ застосування дозволяє найбільш повно задовольнити потреби клієнтів, забезпечити гнучкість постачань й зниження собівартості продукції для підприємства, створити умови для швидкої реакції на зміни запитів споживачів, скоротити виробничий цикл, підвищити оборотність запасів i, по суті, здійснити перехід до стратегії виробництва товарів на замовлення споживачів.

Проведено порівняння виробничо-логістичних стратегій, що побудовані на принципах Push (штовхаюча), i Pull (тягнуча) стратегій та проаналізовано переваги та недоліки їх застосування для підприємства. Аналіз сильних і слабких сторін стратегій дозволяє зробити вибір між системами управління потоками відповідно до умов роботи на ринку та особливостей внутрішніх процесів на підприємстві.

Запропоновано математичну модель вибору принципу побудови виробничо-логістичної системи підприємства та практичні рекомендації до іiі впровадження. Сформовано систему показників, що характеризують ефективність функціонування виробничо-логістичної системи підприємства. В якості ключових критеріїв, що впливають на прийняття рішення при виборі виробничо-логістичної системи виділено наступні показники: надійність постачальника; забезпеченість складськими площами; коливання попиту; продуктивність праці; якість виробленої продукції.

Оцінка показників ВАТ «Молочний альянс» засвідчила, що на даний момент часу виробничологістична система підприємства найбільш повно відповідає вимогам штовхаючої концепції управління потоками. В той же час проведений аналіз надав можливість виявити напрямки над якими необхідно працювати підприємству для подальшого переходу до принципів тягнучої концепції, а саме необхідність покращення взаємодій із діючими постачальниками та пошук нових постачальників. Визначено, що виділені проблеми на підприємстві є важливими факторами побудови виробничо-логістичних систем на принципах витягування. Тому вони можуть бути використані в якості критеріїв, що впливають на прийняття рішення про вибір виробничо-логістичної концепції. 
Ключові слова: виробничо-логістична система, гнучкість, запаси, концепції управління потоками, критерії ефективності, система показників.

\section{ПРОЕКТИРОВАНИЕ ПРОИЗВОДСТВЕННО- ЛОГИСТИЧЕСКИХ СИСТЕМ НА ОСНОВЕ ТЯНУЩЕЙ КОНЦЕПЦИИ УПРАВЛЕНИЯ ПОТОКАМИ \\ О. Н. Загурский, Т. И. Слипуха}

Аннотация. Исследованы особенности проектирования производственно-логистических систем на основе тянущей концепции управления потоками. Ее применение позволяет наиболее полно удовлетворять потребности клиентов, обеспечивать гибкость поставок и снижения себестоимости продукции для предприятия. Таким образом, создаются условия для быстрой реакции предприятия на изменения запросов потребителей, сокращается производственный цикл, повышается оборачиваемость запасов и, по сути, осуществляется переход к стратегии производства на заказ.

Проведено сравнение производственнологистических стратегий построенных на принципах Push (толкающая), и Pull (тянущая) стратегии, проанализированы преимущества и недостатки их внедрения на предприятии. Анализ сильных и слабых сторон позволяет сделать выбор между системами управления потоками в соответствии с условиями работы на рынке и особенностями внутренних процессов на предприятии.

Предложена математическая модель выбора принципа построения производственнологистической системы предприятия и практические рекомендации к ее внедрению. Сформирована система показателей, характеризующих эффективность функционирования производственнологистической системы предприятия. В качестве критериев, влияющих на принятие решения о выборе производственно-логистической концепции, выделены следующие показатели: надежность поставщика; обеспеченность складскими площадями; колебания спроса; производительность труда; качество производимой продукции.

Оценка критериев ЗАО «Россава» показала, что на данный момент времени производственнологистическая система предприятия наиболее полно отвечает требованиям толкающей концепции управления потоками. В то же время проведенный анализ дал возможность выявить направления, над которыми необходимо работать предприятию для дальнейшего перехода к принципам тянущей концепции, а именно необходимость улучшения взаимодействия с действующими поставщиками и поиск новых поставщиков. Определено, что выделенные проблемы на предприятии являются важными факторами построения производственнологистических систем на принципах вытягивания. Поэтому они могут быть использованы в качестве критериев, влияющих на принятие решения о выборе производственно-логистической концепции.

Ключевые слова: производственнологистическая система, гибкость, запасы, концепции управления потоками, критерии эффективности, система показателей.

O. M. Zagursky ORCID 0000-0002-5407-8466. T. I. Slipukha ORCID 0000-000X-XXXX-XXXX. 